\title{
PENGARUH EKUITAS MEREK TERHADAP MINAT BELI ULANG PRODUK WARDAH PADA GENERASI Y
}

\author{
Sazbilla Dwinanda, Indira Rachmawati
}

Fakultas Ekonomi dan Bisnis, Universitas Telkom

Email: sazbillaicha@ student.telkomuniversity.ac.id, indirarachmawati@telkomuniversity.ac.id

\begin{abstract}
ABSTRAK
Penelitian ini mempunyai tujuan agar mengetahui pengaruh dari ekuitas merek pada minat beli ulang. Obyek penelitian yakni konsumen produk Wardah pada generasi Y. Metode Penelitian secara kuantitatif dengan menguji sampel 385 sebagại responden dengan sampel penelitian yaitu konsumen yang pernah membeli produk Wardah dengan usia antara 21- 41 tahun. Analisis data yang dipakai pada penelitian adalah analisis regresi, uji asumsi klasik, uji hipotesis serta koefisien determinasi. Hasil penelitian diperoleh dari pengujian secara parsial yaitu melalui uji $t$ menunjukkan bahwa variabel Kesadaran merek $\left(\mathrm{X}_{1}\right)$ terhadap Minat beli ulang $(\mathrm{Y})$ berpengaruh signifikan pada minat beli ulang produk $(\mathrm{Y})$. Uji t pada variabel Persepsi kualitas $\left(\mathrm{X}_{2}\right)$ pada minat beli ulang $(\mathrm{Y})$ berpengaruh signifikan pada minat beli ulang produk $(\mathrm{Y})$. Uji t pada variabel Asosiasi merek $\left(\mathrm{X}_{3}\right)$ terhadap minat beli ulang $(\mathrm{Y})$ berpengaruh signifikan pada minat beli ulang produk $(\mathrm{Y})$. Uji t pada variabel Loyalitas merek $\left(\mathrm{X}_{4}\right)$ pada minat beli ulang $(\mathrm{Y})$ berpengaruh signifikan pada minat beli ulang produk (Y). Pengujian secara simultan yaitu dengan uji $\mathrm{F}$, dapat disimpulkan Ekuitas merek secara simultan memiliki pengaruh yang signifikan pada Minat beli ulang.
\end{abstract}

\section{Kata Kunci: Ekuitas Merek, Minat Beli Ulang, dan Wardah}

\section{ABSTRACT}

This study aims to determine the effect of brand equity on repurchase intention. The research object is the consumers of Wardah's products in the $Y$ generation. The research method is quantitative by testing a sample of 385 as respondents with the sample of this study, namely consumers who have bought Wardah products with the age between 21-41 years. The data analysis used is regression analysis, classic assumption test, hypothesis test and determination coefficient. The results of this study were obtained from partial testing, namely the test showing that the brand awareness variable $\left(X_{1}\right)$ on repurchase intention $(Y)$, has a significant effect on product repurchase intention $(Y)$. The t test on the perceived quality variable $\left(X_{2}\right)$ on the repurchase intention $(Y)$ has a significant effect on the product repurchase intention $(Y)$. The $t$ test on the brand association variable $\left(X_{3}\right)$ on repurchase intention $(Y)$ has a significant effect on product repurchase interest $(Y)$. The t test on the variable brand loyalty $\left(X_{4}\right)$ on repurchase intention $(Y)$ has a significant effect on product repurchase intention $(Y)$. Simultaneous testing, namely by using the $F$ test, it can be concluded that brand equity simultaneously has a significant effect on repurchase interest.

Keywords: Brand Equity, Repurchase Intention, and Wardah 
ЛRNAL ПMПАH

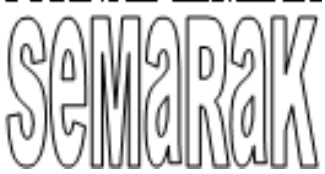

P-ISSN 2615-6849, E-ISSN 2622-3686

\author{
Jurnal Semarak,Vol.4,No.2,Juni 2021, Hal (98-104)
}

@ Prodi Manajemen Fakultas Ekonomi Universitas Pamulang

\section{PENDAHULUAN}

\section{A. Latar Belakang}

Industri kosmetik merupakan salah satu faktor yang melatarbelakangi perkembangan ekonomi Indonesia, dan kebutuhan akan kosmetik merupakan kebutuhan pokok kaum wanita saat ini. Indonesia dianggap sebagai salah satu pasar kosmetik potensial, Indonesia terlihat menjanjikan bagi produsen yang ingin mengembangkannya. Industri kosmetik Indonesia merupakan salah satu sektor kunci yang diidentifikasi dalam Rencana Induk Pembangunan Industri Nasional 2015-2035 (RIPIN) (Kementerian Perindustrian, 2018).

Penduduk Indonesia dengan
kelompok umur 15 - 64 tahun yang termasuk kedalam kelompok usia produktif merupakan kelompok umur yang paling dominan yang memiliki persentase paling besar sebesar 68,7\% (Databoks, 2019). Generasi Y di Indonesia adalah penduduk Indonesia yang lahir pada tahun 1980 2000, yang termasuk kedalam golongan kelompok usia produktif. Generasi Y adalah bagian terbesar dari populasi sehingga menjadikan konsumen paling potensial di pasar, yang mengakibat meningkatnya potensi pasar domestik ini (Ekarina, 2019). Berdasarkan survei ZAP Beauty Index 2018 menunjukan wanita generasi $\mathrm{Y}$ pada zaman sekarang kebanyakan membelanjakan uangnya sebanyak Rp. 600.000 - Rp. 1.000 .000 untuk membeli produk kecantikan, hal ini mendukung industri kosmetik di Indonesia membuat para perusahaan berlomba lomba untuk menawarkan produk dengan kualitas yang terbaik (Nurfadilah, 2018).

Maraknya fenomena hijrah pada kalangan generasi Y, mengakibatkan meningkatnya penduduk generasi $\mathrm{Y}$ milih produk kosmetik yang memiliki sertifikat halal (Wijayanto, 2020). Wardah kosmetik merupakan salah satu merek kosmetik lokal pertama yang mengangkat branding dengan label halal, sehingga telah memperoleh sertifikat halal dari Majelis Ulama Indonesia (MUI), produk Wardah kosmetik mengandung bahan-bahan yang murni dan aman. Sebelum produk Wardah dijual di pasaran dilakukan tes yang disebut blind test untuk memastikan keamanan produk yang dijual (Nurfitriani dan Iriani, 2018). Wardah kosmetik yang diproduksi PT. Paragon Technology \& Innovation, menempati posisi pertama sebagai merek kosmetik paling populer untuk wanita yang menduduki peringkat pertama (Muslimawati, 2017).

\section{Tabel 1 Data Market Share Produk} Kosmetik Indonesia

\begin{tabular}{|c|c|c|c|c|c|c|c|}
\hline No & Mack & $\begin{array}{c}2014 \\
(\%)\end{array}$ & $\begin{array}{c}2015 \\
(\%)\end{array}$ & $\begin{array}{c}2016 \\
(5)\end{array}$ & $\begin{array}{c}2017 \\
(50)\end{array}$ & $\begin{array}{c}2018 \\
(\%)\end{array}$ & $\begin{array}{c}2019 \\
(2)\end{array}$ \\
\hline 1 & Wandah & 14.8 & 17.8 & 15.3 & 14.5 & 15.7 & 16.2 \\
\hline 2 & Poodz & 10.2 & 8.7 & 12.1 & 14.9 & 16.0 & 16.9 \\
\hline 3 & Sanayu & 9.7 & 7.2 & 8.6 & 7.7 & 8.3 & 8.8 \\
\hline 4 & Mustika Ratu & 7.2 & 7.8 & 8.1 & 7.0 & 6.6 & 7.7 \\
\hline 5 & La Iulipe & 4.2 & 3.8 & 27 & 4.3 & 5.7 & 6.1 \\
\hline 6 & Pay & 10.0 & 8.0 & 7.8 & 7.1 & 5.7 & 4.6 \\
\hline
\end{tabular}

Sumber: Utami (2020)

Market share produk kosmetik di Indonesia tahun 2014 - 2019 kian kompetitif yang menunjukan selisih antar merek yang sangat tipis, bahwa market share produk Wardah kosmetik di Indonesia mengalami penurunan, pada tahun 2019 yaitu Wardah menempati posisi kedua dengan persentase sebesar $16.2 \%$ (Utami, 2020).

Selain itu, menurunnya jumlah kategori produk Wardah yang termasuk kedalam top brand index mulai tahun 2018 sampai dengan 2020. Tahun 2018 terdapat 18 kategori produk Wardah yang termasuk kedalam top brand index, namun pada tahun 2019 - 2020 hanya terdapat 12 kategori yang termasuk kedalam top brand index (Topbrandaward, 2020). Indikator pada top brand tersebut secara garis besar sesuai dengan dimensi yang ada pada ekuitas merek sebagai tolak ukur kekuatan merek pada suatu produk, kondisi ini menjadi perhatian yang penting bagi produsen kosmetik Wardah untuk berusaha 


\section{Jurnal Semarak,Vol.4,No.2,Juni 2021, Hal (98-104)}

@Prodi Manajemen Fakultas Ekonomi Universitas Pamulang

lebih keras agar menjadikan produknya unggul di pasaran dengan menciptakan inovasi baru agar menarik perhatian konsumen.

Fenomena yang telah dijelaskan, bahwa penurunan kategori produk Wardah yang masuk kedalam top brand index berbanding lurus dengan penurunan market share produk Wardah Posisi, maka perlu untuk mencari tahu bagaimana posisi merek tersebut dengan mengukur dimensi ekuitas mereknya. Ekuitas merek terdiri dari beberapa elemen yaitu kesadaran merek, citra merek, persepsi kualitas, dan loyalitas merek. Persepsi merek yang baik dibangun melalui ekuitas merek, dapat menimbulkan keinginan konsumen untuk membeli ulang di masa depan (Algustin \& Matoati, 2020). Pembahasan mengenai masalah di atas menjadi tempuan bagi peneliti untuk melakukan sebuah penelitian kepada masyarakat Indonesia penelitian mengenai "Pengaruh Ekuitas Merek Terhadap Minat Beli Ulang Produk Wardah Pada Generasi Y".

B. Rumusan Masalah.

1. Apakah kesadaran merek berpengaruh terhadap minat beli ulang produk Wardah pada generasi Y?

2. Apakah persepsi kualitas merek berpengaruh pada minat beli ulang produk Wardah pada generasi Y?

3. Apakah asosiasi merek berpengaruh terhadap minat beli ulang produk wardah pada generasi $\mathrm{Y}$ ?

4. Apakah persepsi kualitas merek berpengaruh terhadap minat beli ulang produk wardah pada generasi Y?

5. Seberapa besar pengaruh ekuitas merek secara simultan terhadap minat beli ulang produk Wardah pada generasi Y?

\section{Tujuan Penelitian}

Setelah dibuat perumusan masalah dan analisa yang dijabarkan sebelumnya, pnelitian bertujuan:
1. Mengetahui pengaruh kesadaran merek terhadap minat beli ulang produk Wardah pada generasi Y.

2. Mengetahui pengaruh asosiasi merek terhadap minat beli ulang produk Wardah pada generasi Y.

3. Mengetahui pengaruh kualitas merek terhadap minat beli ulang produk Wardah pada generasi Y.

4. Mengetahui pengaruh loyalitas merek terhadap minat beli ulang produk Wardah pada generasi $Y$.

5. Mengetahui seberapa besar pengaruh ekuitas merek secara simultan terhadap minat beli ulang produk Wardah pada generasi $\mathrm{Y}$.

\section{TINJAUAN PUSTAKA}

\section{A. Ekuitas Merek}

Kumpulan seluruh aset serta liabilitas yang terhubung dengan merek untuk menambah bisa juga mengurangi nilai suatu produk atau jasa bagi suatu industri (Wirdamulia, 2019). Mengukur suatu nilai ekuitas dapat melalui dimensi - dimensi yang diantaranya adalah dimensi-dimensi kesadaran merek (brand awareness), asosiasi merek (brand associations), persepsi kualitas (perceived quality), dan loyalitas merek (brand loyality) (Aaker, 1991).

\section{B. Kesadaran Merek}

Kesadaran merek merupakan kemampuan pelanggan untuk mengenali serta mengingat sebuah merek saat memberikan instruksi atau isyarat tertentu, kesadaran merek dipengaruhi oleh merek dan komunikasi eksternal yang diberikan oleh perusahaan (Tjiptono, 2019).

\section{Persepsi Kualitas}

Persepsi kualitas merupakan penilaian konsumen pada keunggulan atau superiotas produk secara keseluruhan. Persepsi kualitas didasarkan pada penilaian diri konsumen dengan kualitas produk (bukan manajer atau ahli) (Tjiptono, 2011).

\section{Asosiasi Merek}

Asosiasi merek merupakan segala sesuatu yang terkait dengan memori pada sebuah merek. Asosiasi merek memiliki 
tingkat kekuatan tertentu dan semakin kuat dengan meningkatnya pengalaman konsumsi dengan merek tertentu (Tjiptono, 2011).

\section{E. Loyalitas Merek}

Loyalitas merek sebagai tingkat kesetiaan konsumen pada suatu merek. Loyaliyas merek merupakan inti dari ekuitas merek yang menjadi gagasan sentral dalam pemasaran karena hal ini merupakan ukuran keterkaitan seorang pelanggan pada sebuah merek (Priansa, 2017).

\section{F. Minat Beli Ulang}

Menurut Hasan (2013:131) dalam Nurfitriani dan Iriani (2018) minat beli ulang merupakan adanya perilaku masa lalu yang secara langsung mempengaruhi minat dan perilaku membeli ulang pada waktu lainnya. Terdapat empat indikator dalam minat beli ulang yaitu sebagai berikut:

1. Minat transaksional yaitu keinginan seseorang untuk membeli produk.

2. Minat referensial yaitu kecenderungan seseorang untuk mereferensikan produk kepada orang lain.

3. Minat preferensial yaitu minat yang menggambarkan perilaku individu yang mendukung produk tersebut. Preferensi ini dapat berubah jika terjadi suatu perubahan dengan produk prefrensinya.

4. Minat eksploratif yaitu menggambarkan perilaku individu yang selalu mencari informasi mengenai produk yang diinginkan serta mencari informasi agar mendukung sifat positif dari produk tersebut.

\section{G. Hipotesis Penelitian}

Berikut dibawah ini dugaan sementara pada penelitian ini sebagai berikut:
H1: Kesadaran merek berpengaruh signifikan pada minat beli ulang produk Wardah pada generasi $Y$.

$\mathrm{H} 2$ : Persepsi kualitas berpengaruh signifikan pada minat beli ulang produk Wardah pada generasi $\mathrm{Y}$.

H3: Asosiasi merek berpengaruh signifikan pada minat beli ulang produk Wardah pada generasi $Y$.

H4: Loyalitas merek berpengaruh signifikan pada minat beli ulang produk Wardah pada generasi $\mathrm{Y}$.

H5: Ekuitas merek secara simultan berpengaruh signifikan pada minat beli ulang produk Wardah pada generasi Y.

\section{METODE PENELITIAN}

Metode yang dipergunakan dalam penelitian ini merupakan metode kuantitatif melalui survei kuesioner dengan google form. Penelitian skor dilaksanakan dalam bentuk skala Likert. Pada penelitian ini kriteria responden untuk dijadikan sampel adalah konsumen yang pernah melakukan pembelian produk Wardah Kosmetik pada generasi Y yang memiliki usia antara $21-41$ tahun di Indonesia sebanyak 385 responden dari konsumen yang pernah menggunakan produk Wardah kosmetik di Indonesia. Analisis data dengan menggunakan SPSS yang dipakai merupakan analisis regresi, uji asumsi klasik, uji hipotesis serta koefisien determinasi.

\section{HASIL DAN PEMBAHASAN}

\section{A. Uji Asumsi Klasik}

\section{Uji Normalitas}

\section{Tabel 2 Uji Normalitas}

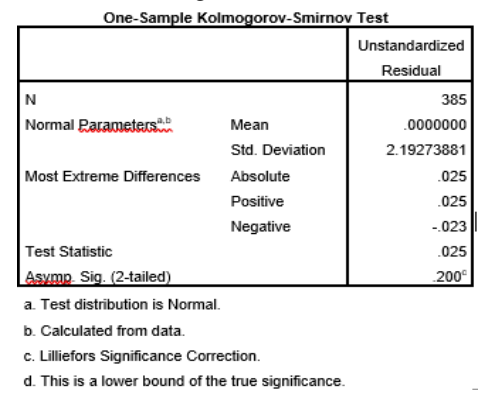


JRNAL ПMПAH

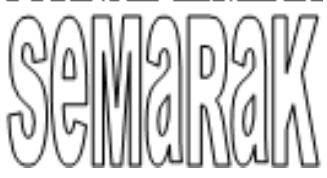

Jurnal Semarak,Vol.4,No.2,Juni 2021, Hal (98-104)

@Prodi Manajemen Fakultas Ekonomi Universitas Pamulang

Hasil uji normalitas diatas, diperoleh nilai Asymp Sig. (2-tailed) 0,200 >0,05. Oleh karena itu, nilai signifikansi lebih dari max error sebesar 0,05 , dan data dapat dikatakan sebagai nilai residual yang berdistribusi normal.

\section{Uji Multikolineritas}

\section{Tabel 3 Uji Multikolineritas}

\begin{tabular}{|l|c|c|}
\hline \multirow{2}{*}{ Model } & \multicolumn{2}{|c|}{ Collinearity Statistics } \\
\cline { 2 - 3 } & Tolerance & VIF \\
\hline Kesadaran merck & .591 & 1.692 \\
Persepsi kualitns & .458 & 2.183 \\
Asosiasi merek & .359 & 2.783 \\
Loyalitas merek & .600 & 1.667 \\
\hline \multicolumn{2}{|c|}{ a. Dependent Variabel: Minat Beci Ulang } \\
\hline
\end{tabular}

Maka terlihat bahwa hasil uji multikolineritas menunjukan bahwa setiap variable dalam penelitian ini, nilai VIF $<10$ dan nilai Tolerance $>0.1$ sehingga dapat disimpulkan bahwa tidak terdapat multikolinearitas dalam data.

\section{Uji Heterokedastisitas}

Tabel 4 Uji Heterokedastisitas

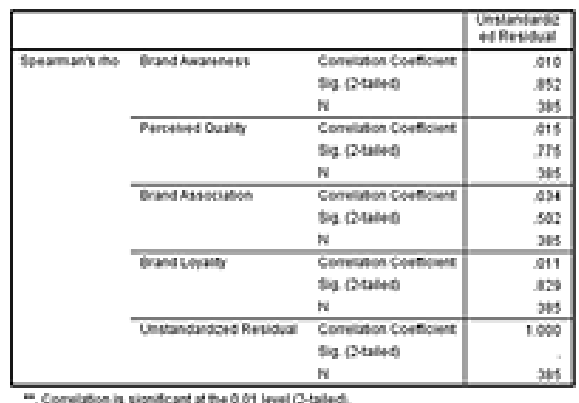

Hasil uji heterokedastisitas metode Spearman's rho, dimana terlihat nilai signifikansi variabel menunjukan nilai > 0.05 . Jadi bisa dikatakan tidak ada heterokedastisitas atau tujuan didalam model regresi tidak terjadi ketidaksamaan varian.

\section{B. Analisis Regresi Linier Berganda Tabel 5 Regresi Linier Berganda}

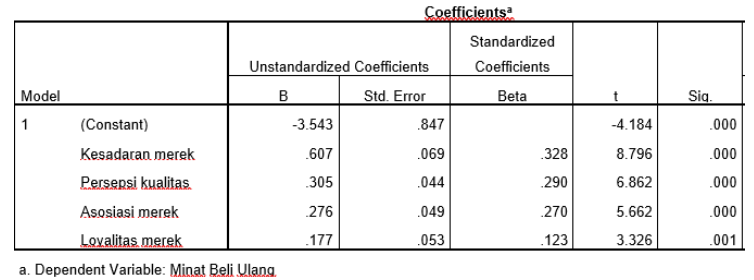

Pada Tabel 5 diperoleh bentuk persamaan regresi linier berganda sebagai berikut:

a Nilai koefisien regresi untuk variabel kesadaran merek (X1) sebesar 0.607 dengan arah positif, artinya jika variabel kesadaran merek (X1) meningkat sebesar satu satuan akan menyebabkan meningkat pula minat beli ulang (Y) produk Wardah pada generasi Y sebesar 0.607.

b. Nilai koefisien regresi untuk variabel persepsi kualitas (X2) sebanyak 0.305 dengan arah positif, artinya jika variabel persepsi kualitas (X2) meningkat sebesar satu satuan akan menyebabkan meningkat pula minat beli ulang (Y) produk Wardah pada generasi Y sebesar 0.305.

c. Nilai koefisien regresi untuk variabel asosiasi merek (X3) sebesar 0.276 dengan arah positif, artinya jika variabel asosiasi merek (X3) meningkat sebesar satu satuan akan menyebabkan meningkat pula minat beli ulang (Y) produk Wardah pada generasi Y sebesar 0.267.

d. Nilai koefisien regresi untuk variabel loyalitas merek (X4) sebesar 0.177 dengan arah positif, artinya jika variabel loyalitas merek (X4) meningkat sebesar satu satuan akan menyebabkan meningkat pula minat beli ulang (Y) Produk Wardah Pada Generasi Y sebesar 0.177.

\section{Uji t}

Tabel 6 Uji t 


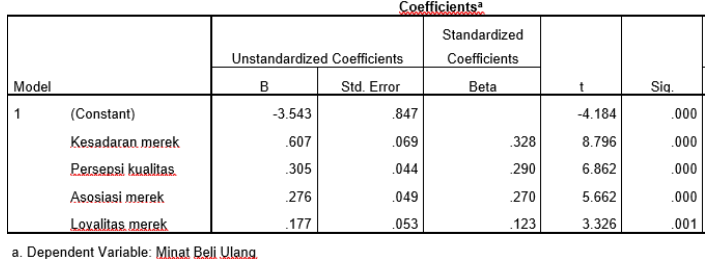

Pada Tabel 6 hasil Uji t sebagai berikut:

a. Kesadaran merek memiliki nilai $t$ hitung > t tabel yaitu $8,796>1,966$ serta tingkat signifikan $0,000<0,05$, maka H1 diterima dan dapat disimpulkan bahwa kesadaran merek (X1) memiliki pengaruh yang signifikan pada minat beli ulang produk (Y) Wardah pada generasi Y.

b. Persepsi kualitas memiliki nilai $t$ hitung > t tabel yaitu $6,862>1,966$ serta tingkat signifikan $0,000<0,05$, maka H2 diterima dan dapat disimpulkan bahwa persepsi kualitas (X2) memiliki pengaruh yang signifikan pada minat beli ulang produk (Y) Wardah pada generasi Y.

c. Asosiasi merek memiliki nilai t hitung $>\mathrm{t}$ tabel yaitu 5,662 > 1,966 dan tingkat signifikan $0,000<0,05$, maka H3 diterima dan dapat disimpulkan bahwa asosiasi merek (X3) memiliki pengaruh yang signifikan pada minat beli ulang produk (Y) Wardah pada generasi $\mathrm{Y}$.

d. Loyalitas merek memiliki nilai $\mathrm{t}$ hitung > t tabel yaitu 3,326>1,966 serta tingkat signifikan $0,001<0,05$, maka H4 diterima dan dapat disimpulkan bahwa loyalitas merek (X4) memiliki pengaruh yang signifikan pada minat beli ulang produk (Y) Wardah pada generasi Y.

\section{Uji F}

\section{Tabel 7 Uji F}

\begin{tabular}{|c|c|c|c|c|c|c|}
\hline \multicolumn{7}{|c|}{ ANOVA" } \\
\hline Mo & & Sum of Squares & df & Mean Square & $\mathrm{F}$ & Sig. \\
\hline \multirow[t]{3}{*}{1} & Regression & 4083.220 & 4 & 1020.805 & 210.098 & $.000^{\circ}$ \\
\hline & Residual & 1846.312 & 380 & 4.859 & & \\
\hline & Total & 5929.532 & 384 & & & \\
\hline
\end{tabular}

a. Dependent Variable: Minat Beli Ulang

b. Predictors: (Constant), Loyalitas Merek, Persepsi Kualitas, Kesadaran Merek, Asosiasi Merek
Nilai $\mathrm{F}$ hitung 210.098 dan nilai signifikan 0.00. Dikarenakan nilai $\mathrm{F}$ hitung (210.098) > F tabel (2.395) dan nilai Sig. kurang dari 0.05 , maka $\mathrm{HO}$ ditolak dan H1 diterima. Sehingga dapat dikatakan secara simultan ekuitas merek berpengaruh signifikan pada minat beli ulang.

\section{E. Koefisien Determinasi}

\section{Tabel 8 Koefisien Determinasi}

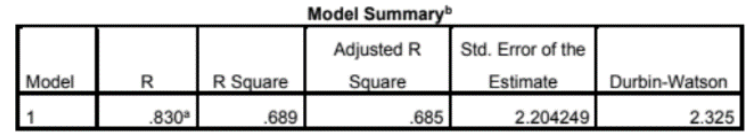

a. Predictors: (Constant), Loyalitas Merek, Persepsi Kualitas, Kesadaran Merek, Asosiasi Merek

b. Dependent Variable: Minat Beli Ulang

Hasil uji koefisien determinasi yang menyatakan nilai $\mathrm{R} 0,830$ dan $\mathrm{R}$ square 0,689 . Nilai $R$ tersebut selanjutnya digunakan untuk perhitungan koefisien determinasi.

$$
\begin{aligned}
\mathrm{KD} & =\mathrm{R} 2 \times 100 \% \\
& =(0,689) \times 100 \%=68,9 \%
\end{aligned}
$$

Artinya hasil koefisien determinasi menunjukkan bahwa variabel independen (kesadaran merek, persepsi kualitas, asosiasi merek, dan loyalitas merek) berpengaruh secara simultan pada minat beli ulang sebesar $68,9 \%$ dan sisanya sebesar $31,1 \%$ menunjukkan bahwa dipengaruhi dengan faktor - faktor yang tidak diteliti pada penelitian.

\section{KESIMPULAN DAN SARAN}

\section{A. Kesimpulan}

Berdasarkan hasil penelitian yang sudah dilakukan pada 385 responden yang berjudul "Pengaruh Ekuitas Merek Terhadap Minat Beli Ulang Pada Produk Wardah Pada Generasi Y" maka diperoleh kesimpulan diantarnya:

1. Variabel kesadaran merek berpengaruh secara signifikan terhadap minat beli ulang produk Wardah pada generasi Y.

2. Variabel persepsi kualitas berpengaruh secara signifikan terhadap minat beli ulang produk Wardah pada generasi Y. 
3. Variabel asosiasi merek berpengaruh secara signifikan terhadap minat beli ulang produk Wardah pada generasi Y.

4. Variabel loyalitas merek berpengaruh secara signifikan terhadap minat beli ulang produk Wardah pada generasi Y

5. Ekuitas merek secara simultan berpengaruh signifinikan terhadap minat beli ulang produk Wardah pada generasi $Y$.

\section{B. Saran}

Berdasarkan hasil penelitian ini diperoleh bahwa kesadaran merek memiliki pengaruh yang paling besar pada minat beli ulang dibanding dimensi ekuitas merek lainnya. Maka dari itu perusahaan Wardah kosmetik sebaiknya lebih mengedepankan strategi bagaimana cara menguatkan ekuitas merek melalui meningkatan kesadaran merek yang diberikan kepada konsumen seperti memberi inovasi produk baru sesuai keinginan konsumen pada generasi $\mathrm{Y}$ dan serta melakukan promosi melalui media sosial dikarenakan generasi Y memiliki karakteristik pengguna sosial media yang fanatik dan informatif agar konsumen sadar akan produk baru yang ditawarkan oleh Wardah kosmetik.

Penilitan ini diharapkan dapat dijadikan referensi untuk penelitian selanjutnya untuk menambahkan variabel independen yang dapat mempengaruhi minat beli ulang seperti variabel brand trust, dan persepsi harga. Penelitian selanjutnya diharapkan memperkecil ruang lingkup penelitian pada suatu daerah tertentu untuk mendapatkan hasil yang lebih spesifik, serta apabila penelitian ini memiliki kesamaan variabel dengan penelitian selanjutnya dengan objek yang berbeda, mengingat semakin banyak bermunculan brand kosmetik lokal saat ini di Indonesia.

\section{DAFTAR PUSTAKA}

Aaker, D. (1991). Managing Brand Equity Capitalizing on the Value of Brand Name. New York: The Free Press.

Algustin, W., \& Matoati, R. (2020).

Pengaruh Ekuitas Merek terhadap Minat Beli Ulang Produk Emina pada Generasi Z. Jurnal Bisnis dan Ekonomi.

Databoks. (2019). 2019, Jumlah Penduduk Indonesia Mencapai 267 Juta Jiwa. Diakses dari: https://databoks.katadata.co.id/datapu blish/2019/01/04/jumlah-pendudukindonesia-2019-mencapai-267-jutajiwa\#

Ekarina. (2019). Tren Perawatan Kecantikan Naik, Industri Kosmetik Dipatok Tumbuh 9\%. Diakses dari: https://katadata.co.id/ekarina/berita/5e 9a51a7c8e5d/tren-perawatankecantikan-naik-industri-kosmetikdipatok-tumbuh-9

Irfanudin, A. M. (2020). Manajemen Pemasaran, Konsep dasar dan Strategi. Banten: CV. AA. Rizky.

Kemenperin. (2018). Industri Kosmetik Nasiona Tumbu 20\%. (Kementerian Perindustrian Republik Indonesia). Diakses dari: https://kemenperin.go.id/artikel/18957 /Industri-Kosmetik-NasionalTumbuh-2018

Muslimawati, N. (2017). Industri Kosmetik di Indonesia Semakin Cantik. Diakses dari:

https://kumparan.com/kumparannews/ industri-kosmetik-di-indonesiasemakin-cantik/full 
Nurfadilah , S. P. (2018). Belanja Kecantikan Perempuan di Indonesia Bisa 3 Kali Lipat dari Belanja Bulanan. Diakses dari: https://ekonomi.kompas.com/read/201 8/08/20/143450226/belanjakecantikan-perempuan-di-indonesiabisa-3-kali-lipat-dari-belanja

Nurfitriani, S., \& Iriani, F. (2018). Citra Merek, Kualitas Merek, Harga dan Pengaruhnya Pada Minat Beli Ulang Produk Kecantikan Wardah. Sebatik.

Priansa, D. J. (2017). Perilaku Konsumen dalam Persaingan Bisnis Kontemporer. Bandung: $\quad \mathrm{CV}$ Alfabeta.

Tjiptono, F. (2011). Seri Mnajemen Merek 01 Manajemen \& Strategi Merek. Yogyakarta: Andi Offset.

Tjiptono, F. (2019). Pemasaran Jasa: Prinsip, Penerapan, Penelitian. Yogyakarta: Andi.

Topbrandaward. (2020). Top Brand Award Survei Merek Terpanjang di Dunia. Diakses dari: https://www.topbrandaward.com/2020/08/top-brand-awardsurvei-merek-terpanjang-di-dunia/

Utami, H. U. (2020). Pengaruh Label Halal Dan Celebrity Endorser Terhadap Keputusan Pembelian Produk Kosmetik Wardah Beauty: Studi Pada Pengguna Produk Wardah Di Bandung Timur. Digital Library UIN Sunan Gunung Djati

Wijayanto. (2020). Gaya Hidup Milenial Dongkrak Industri Kosmetik. Diakses dari: https://radarsurabaya.jawapos.com/rea d/2020/01/14/174764/gaya-hidupmilenial-dongkrak-industri-kosmetik

Wirdamulia, A. (2019). Strategi Pengelolaan Makna Merek. Bogor: PT Penerbit IPB Press. 